publication of fraudulent data can disrupt the research of many. Even if this is correct - and one of the obvious rival explanations is that judgements about failure to assign credit are often tempered by the suspicion that the borrowing was inadvertent - it is far from clear that Hull's evolutionary account has any role to play in articulating the explanation. The lacuna here points to an important flaw in the book. There are some interesting findings about the behaviour of a group of scientists and a very abstract account of the metaphysics of selection. The wheels, however, never quite mesh.

Legend-bashers typically attract science-bashers, and Hull can expect some of his readers to conclude that he has revealed science as brutal warfare among ambitious egoists, a process that has nothing to do with rational argument or the uncovering of truth. Yet the author himself has no truck with fashionable relativisms. He is confident that science makes progress, and that, as a way of attaining knowledge of the world "it beats all other ways hollow" (p.26). Indeed, at his most venturesome, Hull promises to show that science advances because of the polemics, the keen desire for revenge, the intellectual competitiveness, all the marks of the behaviour of his subjects that make defenders of Legend avert their eyes in horror. The promise envisages a thoroughly naturalistic approach to science in which it is shown how certain kinds of intellectual and social forces contribute to the attainment of epistemic goals. But Hull's book does not deliver. Nor could it, for it treats the transmission and origination of scientific ideas at far too abstract and imprecise a level, and it is selfconsciously silent on some of the epistemological questions that any successful development of the naturalistic project should address.

Legend is overdue for replacement, and an adequate replacement must attend to the process of science as carefully as Hull has done. I share his vision of a serious account of the social and intellectual dynamics of science that will avoid both the rosy blur of Legend and the facile charms of relativism. The faults of his book are those of omission, but it is only fair to recognize that they are dwarfed by the accomplishments. Because of the author's deep concern with the ways in which research is actually done, Science as a Process begins an important project in the study of science. It is one of a distinguished series of books, which Hull himself edits, and which in recent years has greatly advanced the history, philosophy and sociology of science. The editor should be more than happy with the author's contribution.

Philip Kitcher is a Professor in the Department of Philosophy, University of California, San Diego, La Jolla, California 92093, USA.

\section{The better way to better health}

Stephen Lock

The Origins of Human Disease. By Thomas McKeown. Basil Blackwell:1988. Pp.233. $£ 22.50, \$ 34.95$.

UNDERPINNING today's craze for jogging and bran is a formidable amount of epidemiology, here cogently summarized in the late Thomas McKeown's last book. Uniting his principal interests in the history of populations and of infections with a forensic power of argument, McKeown concludes that three influences on health stand out: infection, malnutrition and population growth. Medical advances have played only a minor part in improving things, a conclusion that will hardly endear him to the medical establishment any more than did his earlier, similar claims. Nor will politicians welcome his emphasis that we already have much of the knowledge needed to improve health rapidly; what is lacking is effective management and a political commitment to equality of opportunities for good health. But McKeown is equal to any adversary and the blurb is accurate in describing his book as a tour de force.

Recent attacks on health care have been on different grounds: the economic incompetence of its delivery. But only a decade ago (when McKeown came on the scene) the intellectual wrangling was about the role of modern medicine, with allegations that it was positively deleterious to people's general well being. To be sure, medicine has seen off some powerful critics before - Voltaire and Bernard Shaw among them - and in the late 1970 s and early 1980 s it had little difficulty in coping with two of the new ones, Ivan Illich, an "intellectual Tyl Eulenspiegel", as the New England Journal of Medicine described him, was opposed to any aspect of industrialized society, and his appeal to restore pain and suffering to the individual evoked little enthusiasm. Ian Kennedy, the 1980 Reith lecturer, argued with a lawyer's subtlety but his lectures were condemned for their superficiality, particularly his accusation that doctors had usurped control of ethical decisions.

Both Illich and Kennedy provoked a useful debate about what part medicine played in health. Nevertheless, intellectual rigour was added when McKeown joined in, because he had both the appropriate knowledge and the debating skills. A Canadian Rhodes scholar, he had held academic appointments in the basic sciences before going to Birmingham and becoming a foundation professor of social medicine at the age of 32 . At Birmingham he created virtually a new subject, which came to concentrate on the changes in human populations and disease patterns. In some quarters his 1976 Rock Carling lecture on the role of medicine was interpreted as an attack on clinical care, and in a second edition, admitting that he had underestimated its value, he devoted

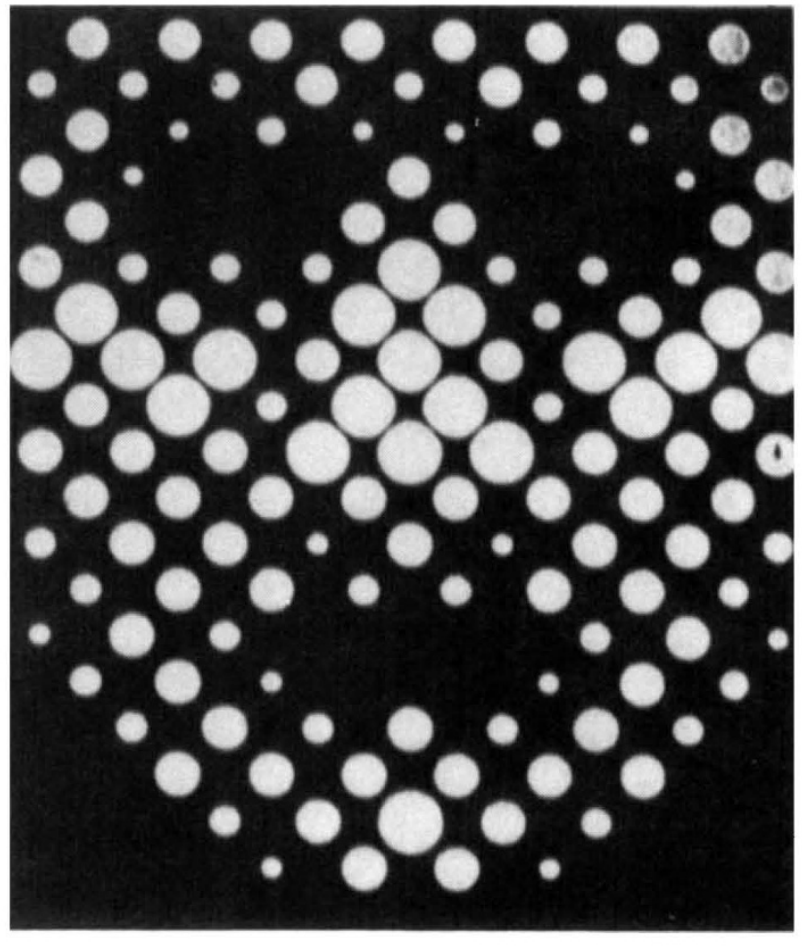

Arresting image -- the World Health Organization's multilanguage poster, produced in 1978 , announcing a $\$ 1,000$ reward for the first person reporting a confirmed case of smallpox acquired by person-to-person transmission. The reward remained valid until the global eradication of smallpox was certified in December 1979. The picture is taken from The Smallpox Story in Words and Pictures, by Abbas $M$. Behbehani, published by the University of Kansas Medical Center. price $\$ 15.95$ (North America), \$16.95 (elsewhere). For a review of WHO's Smallpox and its Eradication see Nature 332, 755 (1988). 
a new chapter to the topic. He did not recant, however, but persisted in his conclusion - that because clinicians saw the body as a machine, whose disorders could be put right in the same way as a car repair, they had overlooked the enormous contribution from modifying disease origins. Moreover, because the role of some influences had been overemphasized (particularly medical care), society had misused its resources and needed to reconsider how such resources were allocated.

In his new book, completed just before he died in June of this year, McKeown classifies human existence into three phases. In the first (hunter-gathering) apart from accidents and tribal wars the important restraints on population growth were infanticide and malnutrition/starvation. The food supply increased 5,000 years ago during the second phase (agriculture), but again the benefits were outstripped by population growth, and malnutrition recurred. And then another predominant cause of illness and death arrived: infectious diseases. Probably originating from animals (measles from dogs, the common cold from horses, tuberculosis from wild cattle, plague from gerbils and influenza from pigs), they could become established and amplified not only against the background of malnutrition but because people now lived together in larger communities, under cramped conditions with poor hygiene.

In the West, the third phase (industrialization) began three centuries ago. Health standards and nutrition dramatically improved, while the population rose and has continued to do so - staggeringly so for the whole world ( 750 million in 1750 , two (American) billion in 1930, five billion today, with probable stabilization at ten billion in 2100). In McKeown's view the early increase in Western populations owed everything to better nutrition, which increased resistance to the infectious diseases, the increase in the late 1800 s also being linked to better hygiene (piped water, sewage and safe milk). Further, communities came to limit their reproduction using contraception, and infanticide disappeared once most children were wanted. Significant medical advances arrived only in the twentieth century, particularly emergency surgery, chemotherapy for puerperal fever and tuberculosis, and immunization against diphtheria and poliomyelitis.

For the individual these and other later developments were obviously important - but, for populations, their role was minor compared with that of better nutrition and bathrooms. Now, however, modern life has produced its flip side: the non-communicable diseases, which, given that human genes have remained unchanged and that these illnesses were absent in wild animals, hunter-gatherers and agriculturalists, McKeown calls diseases of maladaptation. These diseases originate in the environment, through changes in diet (too little fibre and too much food, salt, fat and sugar); the use of alcohol, tobacco and illicit drugs; lack of exercise; and pollution.

One can argue with some features of McKeown's thesis: he is uncritical, for example, about 'bran-wagon' evangelism that explains everything from coronaries to varicose veins as being the consequence of too little dietary fibre. Similarly he surely underplays the value of modern drugs, such as the antibiotics, in prolonging useful and fulfilling life. But in global terms he is right. In future centuries even the West's current spectre, AIDS, will figure as only a blip on the population screen, comparable with the 'minor' effects of bubonic plague or the influenza pandemic - how could we conclude differently in a world where five million children under the age of five still die from diarrhoeal diseases every year?

But the great merit of McKeown's book is that it points to solutions within our grasp. If sufficient food was available to every citizen in the underdeveloped world, health and self-limitation of the population would follow. This approach has worked in China, Sri Lanka and Kerala, where, through the political will to attain equality in health, Western standards have been achieved without improving water quality, sanitation or personal health services (including immunization). As N.H. Antia wrote recently (Nature 335, 584; 1988): "Vaccines . . . should not divert [Indian] attention from the major problem - the need for egalitarian socioeconomic development that alone can eradicate the root cause, namely poverty".

The developed world should recognize that diseases, including the noncommunicable ones, are not inevitable. Action is indeed being taken, from the top downwards. Abolishing cigarettes would eliminate one in three deaths from cancer and smoking is fast becoming unacceptable. The same will happen with excessive alcohol consumption, and in eliminating the $3 \mathrm{lb}$ of chemicals we eat in our food every year. Nevertheless, the developed world has not abolished diseases of poverty; the greatest contribution to health would come from ridding our society of inequalities, which, as the Black Report showed, are still a blot on most countries. And, as McKeown himself wrote some ten years ago: "If a choice must be made, free school meals are more important for the health of poor children than immunization programmes, and both are more effective than hospital beds".

Stephen Lock is Editor of the British Medical Journal, BMA House, Tavistock Square, London WCIH 9JR, UK.

\section{Man and microbe}

\section{Christopher Lawrence}

Robert Koch: A Life in Medicine and Bacteriology. By Thomas D. Brock. Science Tech Publishers, 701 Ridge Street, Madison, Wisconsin: 1988. Pp.365. \$35. Distributed outside North America by Springer-Verlag, $£ 17$.

UNTIL now there has been no book-length biography in English of the German bacteriologist Robert Koch. Indeed, as the author of the present volume notes, "even the German language biographies of Koch are dated and mostly inaccessible" (p.vii). This biographical void is perhaps partly related to Koch's authoritarian personality and his less than impeccable marital life when measured by the standards of the later nineteenth century. Nonetheless it is still surprising because Koch's life contains nearly all of the elements a scientific biographer might wish for: an earth-shattering discovery by a young, unknown and solitary doctor, a rapid rise to fame (and shame), a medical revolution and more than a hint of sexual intrigue.

Koch was born in lower Saxony in 1843 . After a conventional medical education and an unremarkable bourgeois marriage he settled down in 1872 as District Medical Officer in the town of Wollstein, now in Poland. The 1870 s were a turbulent decade in European medicine. The advocates of laboratory science were just beginning to turn the tide against the bedside men, and the proponents of a germ theory of disease were making their voices heard against the defenders of miasma or atmospherical pollution. These two controversies were related. By 1900 bacteria seen through the microscope on the laboratory bench had become the symbol of a new and scientific medicine.

Koch worked in an area where anthrax was rife. For a general practitioner, he was exceptionally well read in the medical literature and, more surprisingly, he was an exceptionally devoted experimentalist. After many months of painstaking research Koch convinced himself that anthrax was caused by a living organism and, more important, that this organism could survive as spores in the soil and in animal hides. Convincing himself was one thing, however. What about the world?

In April 1876 the provincial doctor took his preparations to the illustrious botanist Ferdinand Cohn and the great pathologist Julius Cohnheim at the University of Breslau. Both men were sympathetic to the germ theory and immediately championed Koch's work. From this point Koch entered a much larger public arena. He moved to Berlin and over the next ten years he and his collaborators created many of today's basic bacteriological tech- 